To cite this article: Carlos Nolasco (2018): Player migration in Portuguese football: a game of exits and entrances, Soccer \& Society, DOI: 10.1080/14660970.2017.1419470

To link to this article: https://doi.org/10.1080/14660970.2017.1419470

\title{
Player migration in Portuguese football: a game of exits and entrances
}

\author{
Carlos Nolasco \\ Centre for Social Studies, University of Coimbra, Coimbra, Portugal
}

\begin{abstract}
In a context of intense competition, emphasized by globalization processes, the football industry seeks to maximize performances through an incessant search for high quality skilled players. In a market logic, these players become a scarce asset. They are intensely sought out by teams, which results in an intense migration flow of footballers. Portuguese football is also imbedded in these migrations dynamics. Although it is not a new phenomenon in recent years, Portugal has become a crossroads of migratory flows players, with a large number of foreign players to reach national clubs, and many Portuguese players to go to foreign clubs. The aim of this paper is to observe the migratory trends of football players in Portugal, and identify the migratory routes not only of the foreign players who arrived in Portugal, but also of the Portuguese players who go abroad.
\end{abstract}

Keywords: Migration; sport migration; football; Portugal; globalization

\section{Introduction}

For the first time in UEFA competition finals, in Europa League Final 2011, two Portuguese teams played among themselves; FC Porto and SC Braga. Of the 22 players who started that game, only seven were Portuguese, with the remaining 15 being foreigners. ${ }^{1}$ In the FC Porto team there were; three Brazilians, two Colombians, one Argentinean, one Uruguayan and one Romanian. Also, in the SC Braga team there were six Brazilians and one Peruvian. That game constituted a significant picture of Portuguese football. As in that match, also in the Primeira Liga ${ }^{2}$ the foreigners are the majority of players, coming predominantly from Latin America, particularly from Brazil. In the 2010/2011 season, Portugal was the third country among 69 national associations worldwide, to hire more foreign players, in a total of 182 . Of these, 95 were Brazilian. It is important to note that, in that year, the flow of football players from Brazil to Portugal was the largest migratory route of football work in the world. ${ }^{3}$ These data are corroborated by the Portuguese Union of Professional Football Players ${ }^{4}$ which report that while the Portuguese clubs of Primeira Liga used $93(42 \%)$ national players, the remainder $131(58 \%)$ were foreigners. This context of foreign players being more numerous than the national goes back to the 2006/2007 season, when 287 (54\%) foreign players surpassed the 244 (46\%) Portuguese. ${ }^{5}$ Since then, the presence of foreigners has always been greater by comparison with the national players, which makes football one of the economic activities that employs more immigrant labour in Portugal.

Since the beginning of the football, mobility of players has been a constant, as consequence of its cosmopolitan context and the dynamics of globalization that determined its dispersion and implantation 
throughout the world. ${ }^{6}$ In recent decades, just like other areas of global economy, where we can see a high professional mobility, also the world of sport is on the move. 'An increasing number of elite professional, primarily male, athletes from many sports are now selling their labour outside their home countries', ${ }^{7}$ and 'this process is interwoven with the commodification of sports within the capitalist world economy'.8

Almost all sports are affected by this process ${ }^{9}$; however, the sports labour migration is most noticeable in football. In 2015, a statistical survey by CIES Professional Football Players Observatory ${ }^{10}$ on 6,135 clubs from 458 leagues in 183 countries found that the number of migrant players was 18,660, and that $13 \%$ of teams had foreign players. Thus, parallel to football commentary on passing, dribbling and goals, there is another narrative of the mobility and traffic of players between countries, which in social terms can be seen as an international migration process, reflecting many of the features of the 'age of migration'.11

This paper results of a research on migration of highly qualified athletes, in particular the migration of football players in Portugal; the results presented here partially illustrate this reality, especially the quantitative dimension of this social phenomenon. The aim of this paper is to observe the migratory trends of footballers in Portugal, and analyse the mobility of Portuguese and foreign players signed up with Primeira Liga clubs in Portugal between the 2007/08 and 2011/12 seasons. When analysing the combination of players' migratory routes, it is possible to identify different types and intensities of mobility in national football. The picture that emerges from this analysis illustrates how Portuguese football fits into the global transaction of athletes, and reflects the trends in the international migration of sports labour. Thus, this essay seeks to make known the phenomenon of sports migrations in Portugal, a reality completely absent in the studies on migrations in sports work, contributing with this empirical dimension to a wider conceptualization of the analytical references of the phenomenon in question.

\section{Labour migration in football within the context of globalization}

In all sports, in all competitions, on every continent, athletes are on the move, from one country to another. ${ }^{12}$ This is not a new phenomenon; however, in recent years, it has intensified on a global scale, becoming more complex with the diversification of migratory origins and destinations. Today we are seeing the formation of heterogeneous teams with different backgrounds, identities, languages and ethnicities. In many circumstances, home-grown athletes are a minority in the make-up of teams. A significant proportion of this sporting miscegenation is a consequence of general migratory flows. ${ }^{13}$ However, sport itself is triggering and feeding migratory flows as a result of sporting activities. It is therefore not unusual today to find players representing clubs in countries other than their own, ${ }^{14}$ or representing the national teams of countries in which they themselves were not born. ${ }^{15}$ The migration of sporting talent is therefore a striking and significant feature on the global sports map, the result of 'a contemporary sporting culture whereby athletic labour flows increasingly traverse geographical, political, cultural, ethnic, and economic boundaries'. ${ }^{16}$

In recent decades, football has changed enormously. This transformation is clear in the fact that sport results no longer simply translate into wins and losses, but also in sponsorships, advertising, TV rights, merchandising and fluctuations in the club budget. The speeches of tactics and techniques coexist today with the mercantilist strategies to maximize profits. Clubs have become companies oriented towards profit, directors now use the language of business and fans have been converted into spectators and potential customers. ${ }^{17}$ Now that football has been transformed into an economic game, it has become imperative to acquire players able to turn the aspirations of clubs, sponsors and fans into victories. When these players cannot be found at home, or the ratio of supply and demand favours other recruiting grounds, they are sought outside the country, thereby triggering migration processes.

The initial interpretation of these sports' work migrations was made from the view point of globalization. First by Bale ${ }^{18}$ and then by Bale and Maguire,,$^{19}$ sports migrations were interpreted as a segment of contemporary migration, determined by the trends of sport globalization. In this perspective 
sports migrations occur as result of industrialization and commodification of sport, as well as the constitution of a global sports system, which, in turn, is inserted in the broadest process of globalization.

From this perspective, and within this neoliberal business logic, there are several facts that have intensified footballer migration on a global scale. The reorganization of national and international football competitions, particularly in Europe, with demands for high levels of competitiveness and spectacle, and therefore with need of the best players. Television broadcasting of matches, which has injected money into the world of football, provides clubs with the resources to recruit players in the wider market. The formalization of the players' agent status in 1991 by FIFA, in order to facilitate the mobility of players, converted them into agents of the football labour migration. Clubs scouting departments were created to identify potentially talented young players in other countries, thus contributing to international migration of footballers. And probably the most important of all the facts that contributed to the liberalization of the player transfer market was the Bosman case, which ended with the nationality clause for European players, and with the economic compensation at the end of their contracts. Thus, 'élite labour migration is now an established feature of the sporting global village', ${ }^{20}$ and in European leagues 'foreign players have become a natural feature of the footballing landscape'. ${ }^{21}$

Given these dynamics, several authors, namely Magee and Sugden, ${ }^{22}$ Darby, ${ }^{23}$ Taylor, ${ }^{24}$ Poli, ${ }^{25}$ Takahashi and Horne, ${ }^{26}$ and also Maguire, ${ }^{27}$ among others, assume a critical position. They contextualize the international migrations of footballers in a world system, where migratory flows originate in the peripheries or semi-peripheries head towards the centre, in particular to the most competitive and wealthy leagues in Europe. Thus, footballer migrations reflect the existence of a process of functional integration of spaces on a transnational scale, within which the different national championships are located in a regime of differentiated interdependence.

These movements from the peripheries to the centre can be interpreted as a result of power relations and market logic. Also, these situations reflect a process of deskilling, in which the clubs of the central countries exploit the less developed semi-peripheries and the underdeveloped peripheries, which have invested time and resources in the production of football talent which later will find it difficult to profit for themselves. ${ }^{28}$

This migration of sports labour cannot, however, be reduced to a purely economic interpretation. It is important to consider in addition to the transcendent forces of globalization, that sports labour migration are made of people, players with personal stories that reflect specificities of the places where they come from and the places where they go. ${ }^{29}$ The various actors involved in these mobilities develop adapted strategies to the spaces in which they work, with the purpose of obtaining diverse benefits and capital gains. ${ }^{30}$ There is a complex and multifaceted set of interrelated variables, whether economic, political, historical, geographical or cultural which may broadly help to interpret these migrations. ${ }^{31}$ Therefore, despite the diversification of players' migratory routes through the inclusion of new gaps in the international transfer market, old affinities, especially colonial, are very important in determining migratory trends in some leagues. For example, the predominance of Brazilian players in Portugal, ${ }^{32}$ players from Latin American countries in the Spanish and Italian leagues, or Africans in the French league, is illustrative of this web of affinities. ${ }^{33}$

\section{Brief historical reference to the mobility of footballers in Portugal}

This is not the time to tell the story of the migration of Portuguese football. However, to understand and contextualize the current migratory dynamics of players in Portugal, it is important to point out some of the moments and trends relevant to this process.

The mobility of players in Portugal is a consequence of two trends: the dynamics of globalization which have characterized football from its beginnings, contributing to its spread around the world; and the international and national political dynamics which influenced sports developments and their institutionalization. Football arrived in Portugal in the last quarter of the nineteenth century. Despite controversies over the date and place of where the first football match was played, there is in all references the fact that football arrived in the country via the British, or via some Portuguese who had 
been in England. Coming from a country where the concept of sport was associated with modernity and social development, this sport quickly gained a significant following nationwide. This makes it impossible to identify the first foreigner to have played in Portuguese football, precisely because the origins of football in Portugal were determined by foreigners.

The first foreign player to be hired exclusively to play football in Portugal was the Hungarian Mihaly Siska, in 1924, who moved from Vasas Budapest to FC Porto. This was a controversial hiring, as it reflected the thought that 'there is no glory in winning with a professional and foreign player'. ${ }^{34}$ In turn, the first Portuguese to play abroad was Francisco dos Santos, who played for Lazio of Rome between 1906 and 1908. As a footballer and student of Fine Arts living in Rome to study sculpture,

Francisco dos Santos started playing football in addition to the scholarship he received. ${ }^{35}$

Thereafter, and until the 1970s, recorded cases of Portuguese players emigrating were merely incidental, unusual and dispersed over time. Examples include: Luis Vieira who went to Botafogo, Brazil in 1913; Rogério Carvalho who also went to Botafogo in 1947; Jorge Mendonça who went to Deportivo Coruna in Spain in 1958; and Jorge Humberto who went to Inter Milan in 1961.

As for the entry of foreigners to Portugal, more players of Hungarian origin were contracted in the 1920s. In the mid 1930s, the first Brazilians specifically hired to play football arrived and, before World War II some Yugoslavian players were contracted from the French league. After the war, with Portuguese football striving to become professional, foreign players featured in club squads in greater numbers.

Simultaneously with the immigration of foreign players to Portugal, came the colonial flow of African footballers. In view of the development of football in the Portuguese African colonies, and the importance that some African players had in local tournaments, the metropolitan clubs became interested in employing them in the 1930s. ${ }^{36}$ The recruitment of African players was not restricted to Portugal. France and Belgium also took advantage of players born in their colonies, using them initially in clubs and later in the service of their national teams. ${ }^{37}$ Mainly from Angola and Mozambique, the players who came to Portugal included 'Viroscas', Peyroteo, Miguel Arcanjo, Matateu, Mário Wilson, Juca, Hilário, Águas, Costa Pereira, Mário Coluna, Vicente and the most famous of them all Eusébio, considered one of the best players ever. These players, immigrants in the colonizing process, served the interests of the state when the colonial wars began in 1961 and Portugal gradually became more and more isolated internationally. The international success of Portuguese football in the $1960 \mathrm{~s},{ }^{38}$ with teams made up of many African players, helped the State to counter international charges of racism and colonialism. ${ }^{39}$

In the early 1970 s foreigners internationally renowned had started to arrive at Portuguese football. The first was the Argentine Yazalde, hired in 1971 by Sporting CP, followed in 1974 by the Peruvian Cubillas to play at FC Porto. At the same time, the Portuguese revolution of April 1974 and the consequent fall of the colonial empire put an end to the flow of African footballers to Portugal. The only two clubs in the Portuguese Primeira Liga that had not yet hired foreign players, Académica Coimbra and SL Benfica, were forced to do so to keep themselves competitive. For Benfica to hire the first foreigner, a general meeting was required, in July 1978, to amend the statutes of the club. ${ }^{40}$ From that moment on, in Portuguese football, immigrant players joined an ever-growing list among which there are great names in big clubs, and many others, almost anonymous, in lesser known clubs.

With regard to the emigration of Portuguese players abroad, from the 1970s, there are two migratory trends: players at the end of career, hired by clubs in Canada and the United States, and whose aim was 'to make money'; and young players, hired by Spanish and French clubs, attracted by high wages and competitive demands. In the 1980s, the departure of Chalana for Bordeaux, Paulo Futre for Atlético de Madrid and Rui Barros for Juventus, as well as the two world titles won by Portugal at under-20 level, made Portuguese players very coveted internationally, triggering an increasingly intense flight of domestic players. This flow remains uninterrupted to the present day; in 2015, Portugal was the ninth country in the world with the most expatriate players, and the fifth at European level, with a total of 392 footballers playing abroad. ${ }^{41}$ 
In the last few years there has been an increase in the numbers of foreign players in Portuguese Primeira Liga clubs. During the 1990/91 season, foreign signings made up $30.9 \%$ of all players. In the 2006/07 season, the number of foreign players exceeded home-grown players for the first time, a

situation that has persisted, albeit with slight variations, up to the present. ${ }^{42}$ The Portuguese football league, at European level, is one that has a highest proportion of foreign players. In 2008, the percentage of expatriate players in the Portuguese Primeira Liga was $53.7 \% ; 43$ in 2015 , this percentage increased to $55.6 \%{ }^{44}$

This brief contextualization helps understand the dynamics that have progressively placed the Portuguese football labour market in the global sports arena. Next, we will present a characterization of foreign players in Portugal, as well as routes and migratory dynamics which mark the national football. Beforehand, there will be a methodological justification which will show how the collection of these data was processed.

\section{Methodological summary}

The quantitative analysis of the presence of migrant footballers in the Portuguese championship comes from a survey conducted between the 2007/08 and 2011/12 seasons, which included all players registered in a Primeira Liga club. The database, covering the five football seasons, was prepared by cross-referencing three sources: the Portuguese Professional Football League (LPFP) website, ${ }^{45}$ where players from each club in the competition are registered; the websites of the clubs in the Primeira Liga, which show the players that make up the squads; and the ZeroZero website ${ }^{46}$ which records the career path of these players. The three sources have discrepancies in the number of players in the clubs in each of the seasons. However, cross-checking the information makes it possible to confirm the makeup of the squad, record players and keep track of their professional career. The LPFP and club websites are more official in character, which legitimizes the data collected, while the ZeroZero website is a form of informal control, allowing you to investigate circumstances in players' career paths that were not clarified in the two previous sources.

In the construction of the database were considered some methodological criteria for the registration of players. The registration of players was made twice during each season: at the beginning and at the end in order to obtain players transfers' information, in the middle of the seasons. Thus, for each foreign player a record of their migratory course was made before arriving in Portugal; during the period in which they were in Portugal; possible departures to other foreign clubs or return to the country of origin; or, if they were still in Portugal in the end of the period considered. All players that were recorded in the period under consideration were signed up to play with a Portuguese Primeira Liga club for at least half of one season. Because the information on the dual nationality of the players is not revealing, and doesn't apply to all players, players' nationality was taken to mean the country where the players were born. The player's club was taken to be the club which he was registered for play at a specific time, regardless of the employment agreement kept with another club.

The great difficulty of this survey is the meandering character of the players' migratory pathways. These migrants are subject to intense internal and international mobility, for sometimes short periods of time, and enter clubs in countries with very different sporting calendars. In other words, these migrants are players with short-term contracts at their destination, which is symptomatic of the high mobility that is a feature of sporting migration.

\section{Foreign players in Portuguese football: who are they?}

In the football seasons 2007/08 to 2011/12, for the 23 clubs $^{47}$ that competed in the Primeira Liga, 1,150 players were registered. Of these, 667 were foreigners and the other 483 were Portuguese. The percentage of foreign players in each of the periods in question has always been higher than that of the domestic players, ranging from the $58 \%$ in the $2007 / 08$ season to $55 \%$ in the $2011 / 12$. 
With regard to the origins of all the foreign players in terms of the continent where they were born, it was found that $66.3 \%$ were from South America, $15.7 \%$ from Africa, $14.9 \%$ from Europe, $1.6 \%$ from Asia and $1.5 \%$ from North America and the Caribbean. Oceania had no players in Portugal in the period in question. These 667 players were from 64 different countries, which suggests a certain cosmopolitanism in Portuguese football. However, 26 of these countries were represented by only one player, and 10 countries had no more than two players. In other words, the sum of these 36 nationalities, which is equivalent to over half of nationalities presented in Portuguese football, represents only $6.6 \%$ of the total of foreign players, which mitigates the cosmopolitan image of Portuguese football. This circumstance is due to the over-representation of players of one nationality. Brazil alone, with 373 players, represented $55.1 \%$ of total immigrant players in Primeira Liga. This figure is consistent with the statement by Poli48 that the migratory route between Brazil and Portugal is one of the busiest in the world of football. Two circumstances help to explain this situation: first, the fact that Brazil is the country of football, a country of many players which speculates on their value and transfers them to every continent in significant numbers ${ }^{49}$; on the other hand, the historical relationship between Portugal and Brazil, with many common cultural elements, including the language, and the existence of a treaty of friendship and cooperation between the two countries, ${ }^{50}$ and in addition a large community of Brazilian immigrants in Portugal.

The prominence of Brazilian players is even more significant by comparison with Argentina, which was the second highest nationality with 40 players, and France, third, with 28 players. The reason for the prominence of Argentinians in Portuguese football is related to the dynamics of globalization in the labour market, to the extent that Argentina is one of the countries from which most footballers emigrate. It is therefore possible to find players of this nationality in almost all countries, and Portugal is no exception. France is also one of the countries that exports most footballing labour. ${ }^{51}$ However, the number of French players in Portugal is also directly related to one club, Naval Primeiro de Maio, which had a former emigrant in France as its president, and still had a network of privileged contacts with France.

Angola, Cape Verde, Guinea-Bissau and Mozambique, altogether, the Portuguese-speaking African countries, had 35 players, which translates as $5.2 \%$ of the total volume of foreign players in Portugal. ${ }^{52}$ The low prominence of these players is due, to a large extent, to the process of dual nationality; this means they are counted as Portuguese players which obscures their African origin.

\section{Migratory routes of footballers in Portugal}

In addition to the distinction between domestic and foreign players, the 1,150 players who were listed can be divided into two other categories: those who are or have already been migrants, and those who never migrated. To the 677 foreign players in Portugal who were consequently involved in a migration process, another 189 Portuguese players may be added who have had experience of migration. This makes 866 players who in the period under consideration had some migratory experience, a ratio of $75.3-24.7 \%$ who have not had any experience of this type. This means that, of the total of 1150 players, 3 out of 4 have had migratory trajectories.

In the world of football, each migration has a biographical history attached. The need to reduce this complex multiplicity of possibilities gives rise to a process of simplifying migration by grouping migrant players into different types, according to their particular journeys and most obvious features. Time, distance, legal and labour issues, among other variables, are the usual criteria for the types of migrations, ${ }^{53}$ while for sports labour migrations it is worth highlighting aspects that are specific to the sport itself, in particular motivation, individual experiences and predictions for migratory routes (Maguire ${ }^{54}$ and Magee and Sugden ${ }^{55}$ ).

The registration of the 866 migrant footballers in the Portuguese Primeira Liga allows the elaboration of a typology of their migratory tendencies. While not large for determining profiles, this does however allow us to classify migratory routes, the criteria being players' arrival or departure from Portuguese football. Considering the migratory route of those 866 footballers, it is possible to trace five specific 
categories: (a) Portuguese players who emigrate; (b) foreign players who have their first migratory experience in Portugal and come directly from their country of origin; (c) foreign players who come from their country of origin, but with some migratory experience in another country; (d) foreign players with a migratory trajectory prior to arriving to Portugal from another country other than that of their origin; (e) foreign players starting their professional career in Portugal. Each of the categories in this typology is further divided into three subcategories: (a) footballers migrating to Portugal and returning to their country of origin; (b) players migrating to Portugal who then continue their migratory route in countries other than that of their origin; (c) players migrating to Portugal and remaining in the country. ${ }^{56}$ Each subcategory, in turn, breaks down further into various situations, resulting from the complexity of the professional career of each player.

There were 189 Portuguese players who between the 2007/08 and 2011/12 seasons were at some point signed up with Portuguese clubs, and who had previously or in the subsequent period some migratory experience, representing $21.8 \%$ of total migrant players (Figure 1). Of these, 95 players had emigrated and still remained outside Portugal, although 31 had returned, temporarily, before emigrated again.

There were another 89 Portuguese players in the Primeira Liga at the end of the survey who had experienced migration, but were in the country at that time. Of these players, 18 repeated the migration process and subsequently returned to Portugal. Of all the Portuguese players with migratory experience, five have become professionals in foreign clubs, later returning to Portugal.

The second category refers to foreign players who had their first migratory experience by immigrating to Portugal (Figure 2). With 437 players, equivalent to $49.3 \%$ of the total migrant players in the Primeira Liga, this is the largest category, which is due to two important circumstances: first, a strategic option developed by Portuguese clubs that favour hiring young, inexpensive players without international experience for subsequent sale/valuation, and therefore these players have in Portugal their first exit; second, migration to Portugal is conceived, for many of these players, as a preliminary step that allows further mobility to other European leagues.

Of all the players who make up this category, 182 have returned to their home country after they have been in the service of Portuguese clubs. Out of these, 171 did so directly, and the other 11 immigrated to other countries, returning again to Portugal, and only later returning to their own country. In the second sub-category, 116 players chose to leave Portugal to go to other countries. The third sub-category refers to the 139 players who remained in Portugal. For each of these situations there are complex migratory routes, involving several exits and returns from Portugal to countries of origin and other third countries.

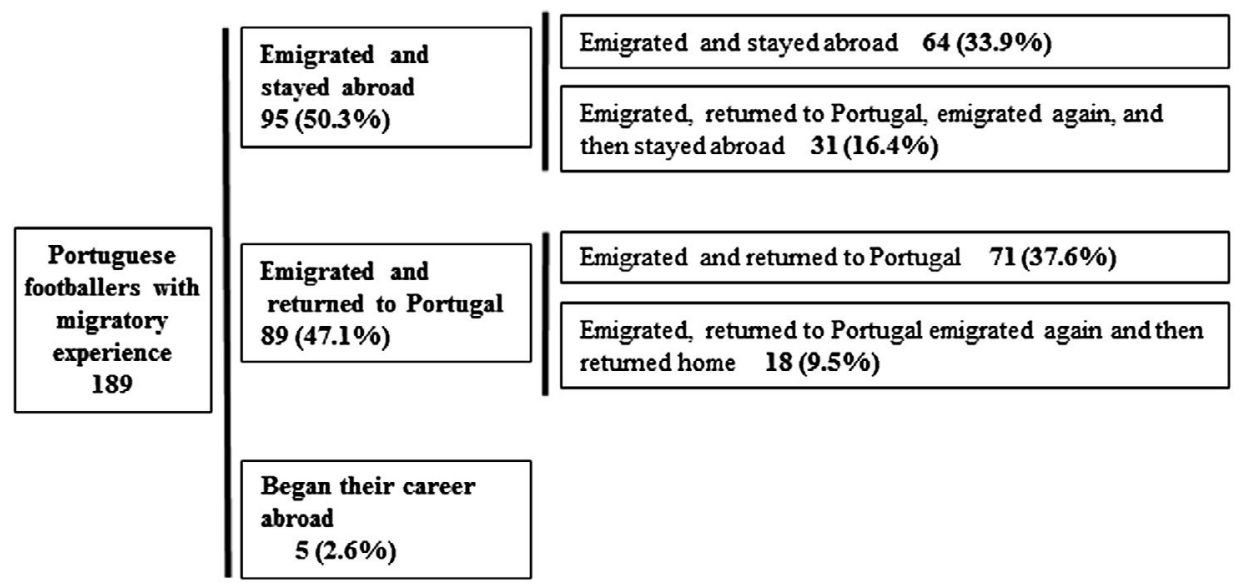

Figure 1. Portuguese footballers with migratory experiences. 


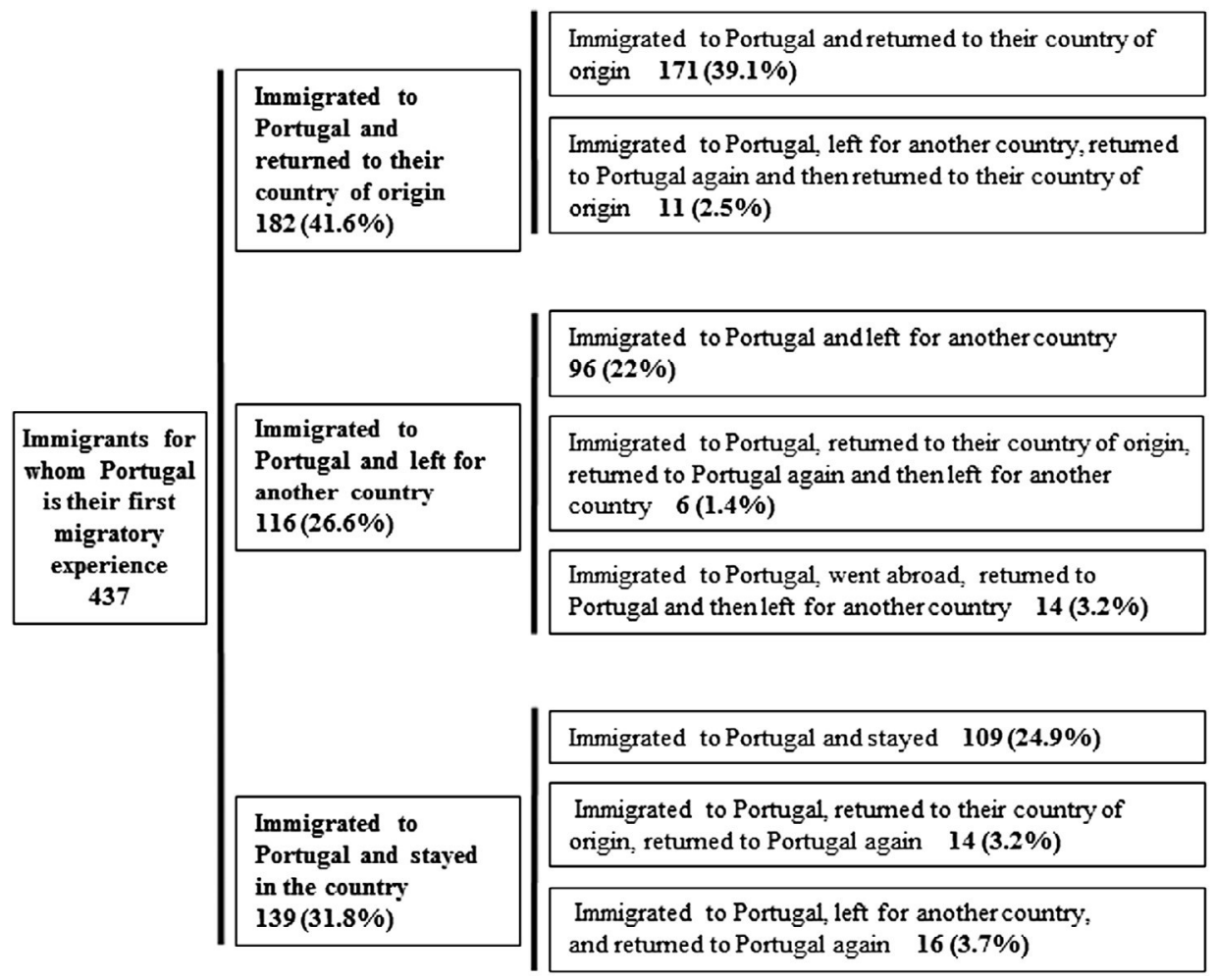

Figure 2. Foreign players for whom Portugal is their first migratory experience.

The third category follows on from the second and refers to players who, despite reaching Portugal from their countries of origin, already experienced migration and return to their respective countries (Figure 3). These players account for $6 \%$ of total footballers with migratory experiences in Primeira Liga. Their reduced prominence in Portuguese football is due to the fact that they are players of high mobility, and spend little time in the same club or country. The value of the subcategory referring to foreign players who remain in the country is also demonstrative of this situation, with only 9 staying in Portugal. The subcategory of players who returned to their country of origin is the most significant, with 23 athletes. Only 16 did so immediately, because the remaining seven had routes involving exits, entrances and returns either to Portugal or to their country of origin.

The fourth category refers to players who immigrated to Portugal coming from countries other than their own (Figure 4). In other words, they left their country, were hired by foreign clubs and after that or other migratory experiences, came to Portugal. The 138 players who are part of this category represent $15.9 \%$ of total migrant footballers.

This category of players is also characterized by significant mobility. If we consider the subcategories, it can be seen that $55.1 \%$ of these players continue their migratory journey. In other words, Portugal represents a stopover on the way to other countries. Taking into account the profile of foreign players in Portugal, this assumes that they use Portuguese football as a showcase to show off their talent to other European clubs. For $29 \%$ their migratory path is to continue in Portugal, but $6.5 \%$ of them leave for other countries and then return to Portuguese clubs. In turn, $15.9 \%$ returned to their country of origin.

The fifth category includes foreign players who started their professional career in Portugal (Figure 5). These players account for $5.8 \%$ of total footballers with migratory experiences. These are mainly players who joined the youth teams of Portuguese clubs and when they became senior turned professional and stayed in Portugal. Return to country of origin happens, then, only for 14 and $34 \%$ 


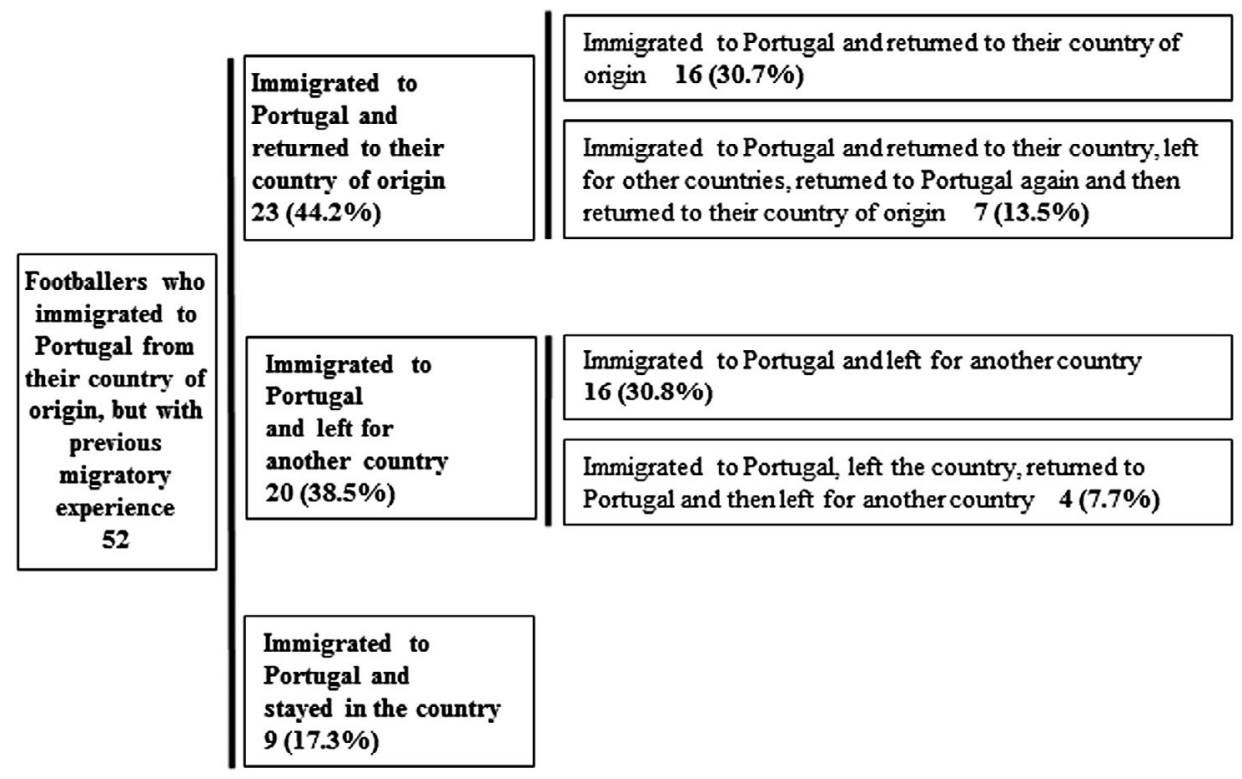

Figure 3. Foreign footballers from their country of origin, but with previous migratory experience.

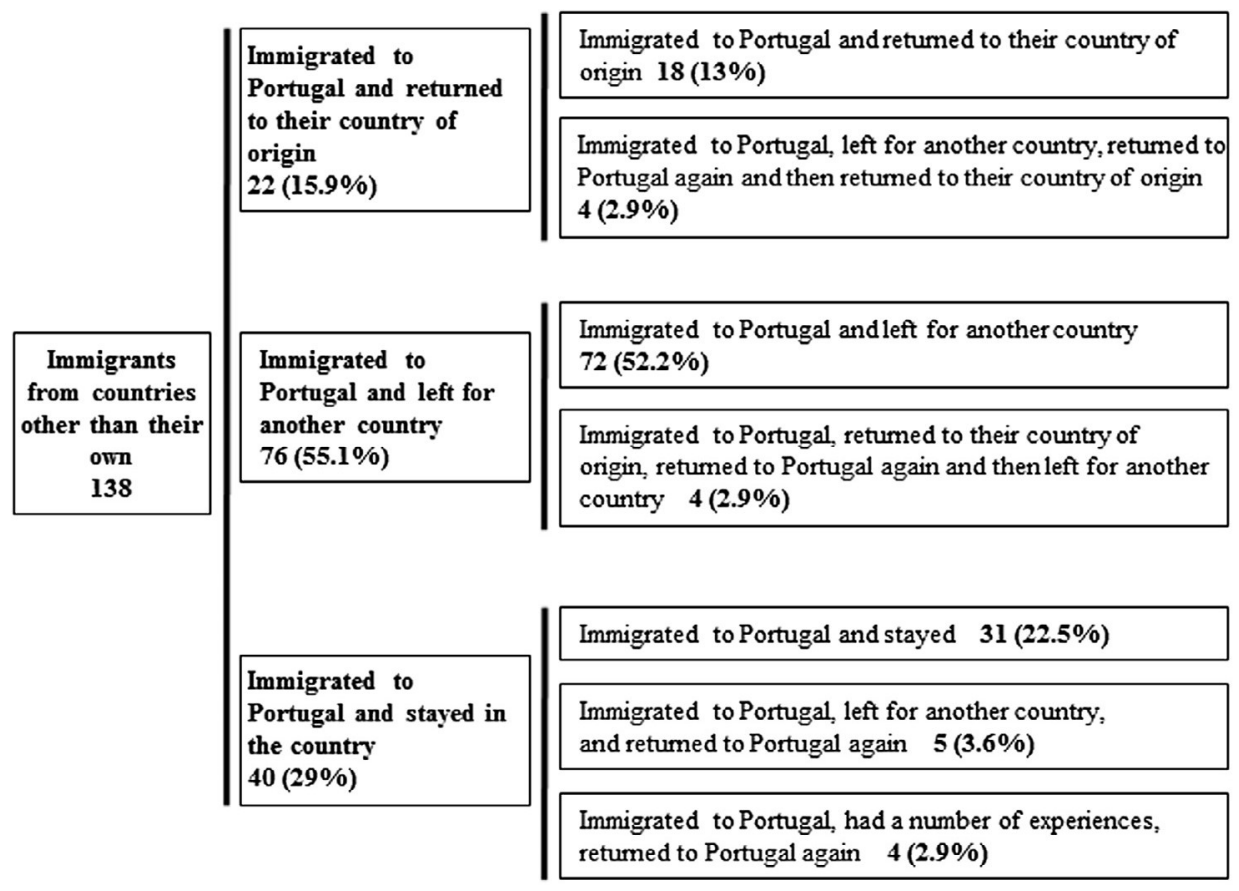

Figure 4. Foreign footballers from countries other than their own.

continue their migratory process to another country. It is significant to note that more than half of these foreign players remain in Portugal.

The typologies of migrant athletes of Maguire ${ }^{57}$ and Magee and Sugden ${ }^{58}$ are not particularly useful for the characterization of the categories presented on the migratory routes of Portuguese football. 


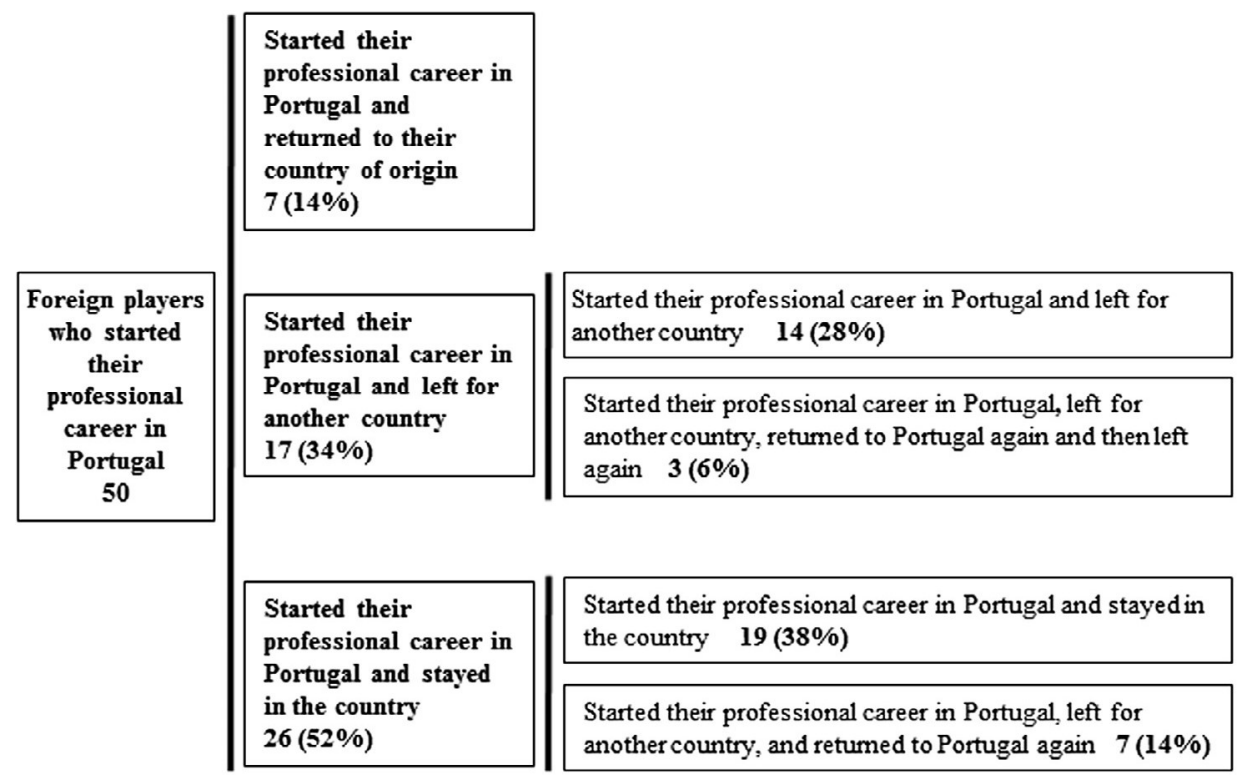

Figure 5. Foreign players who started their professional career in Portugal.

These typologies were elaborated for specific works, through qualitative methodologies, applied to a limited number of athletes. The categories presented here do not allow us to state whether the Primeira Liga footballers are pioneers, mercenaries, ambitionist, exiled, expelled, nomadic cosmopolitan or superstar celebrities. The categories we draw, only allow an approach to the types of returned and settler.

The returned are the players who, after migrating, return to the country of origin. The observation of the migratory routes of the players in the Primeira Liga shows that there are several processes of return. The number of foreigners returning to their respective countries is 396 , corresponding to $58.4 \%$ of the total number of foreign players who, in the five seasons were in the Primeira Liga. The Portuguese footballers who returned to Portugal after migrating was 94 , which means that half of these players have returned. Although it is not a process of return to the country of origin, it is significant to point out that 99 of the foreign players, or $14.6 \%$, after leaving Portugal came back to Portuguese clubs.

The settler category corresponds to the athlete who migrates to a destination and stays there for a period longer than four years. Conclusions about this category can only be taken in relation to length of stay of foreign players in Portugal, because the data regarding the permanence of the Portuguese players abroad are not certain, and may be characterized more by mobility than by permanence. Thus, it is considered that the settlers of Portuguese football are those who have been in Portugal for more than four years; in our study 149 players, corresponding to $22 \%$ of the total number of foreign players were in this situation.

Given the high mobility of players, following the sometimes unusual career paths of successive exits and entrances, it is difficult to assign them to rigid categories. This exercise of categorizing players by migratory route is necessarily limited, therefore, to the extent that reality is always more complex than the frameworks designed to describe it.

From the data presented, it is clear that the footballing profession is a high turnover activity. The mobility record of 866 migrant players shows that most have an experience that relates to one or two countries. Thus, of foreign players in Portugal, 290 (42.8\%) had only Portugal as a destination, 221 $(32.6 \%)$ in addition to Portugal spent time in another country and the remaining 91 (13.4\%) were in three countries, while $75(11.1 \%)$ were in four or more countries. Among these players, albeit a smaller number, there are some authentic globetrotters, in particular one player who has played in ten countries and two in nine countries. As for the Portuguese abroad, a relatively similar situation 

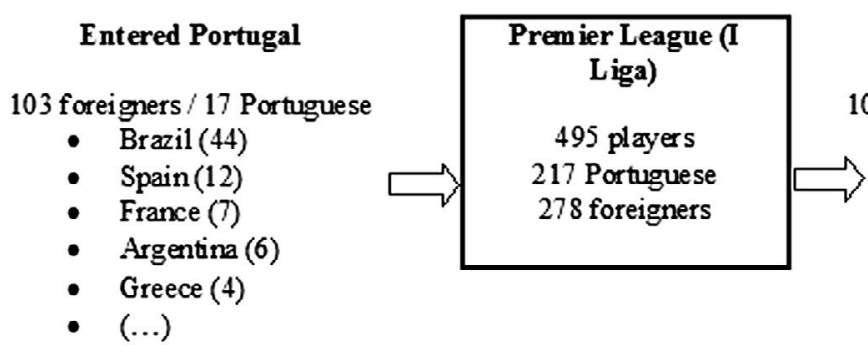

\section{Left Portugal (146)}

108 foreigners $/ 38$ Portuguese

- Brazil (34)

- Spain (18)

- Romania (10)

- Cyprus (7)

- England/China (5)

- (..)

Figure 6. exits and entrances of players in the Primeira Liga 2010/11.

emerges, i.e.: $128(67.7 \%)$ of players migrated only to one country, $35(18.5 \%)$ to two countries and 26 players $(13.8 \%)$ to three or more countries, one of whom spent time at clubs in five different countries.

The significant mobility of Portuguese football can be illustrated by taking a specific season as the unit of analysis, and looking at the corresponding exits and entrances of players from clubs. With reference to the 2010/11 season in the Portuguese League, and identifying the origin of the players from abroad joining the squads of Portuguese clubs, while analysing how many of the 495 players registered at that time came the following season (Figure 6), it can be seen how Portuguese football works in fact as a hub of intense activity which receives and redistributes players.

The 2010/11 season started with 120 new arrivals to Primeira Liga clubs. Of these, 17 were Portuguese players who were returning to the country, and 103 were foreign players. The countries that provided the most players to Portugal were Brazil, Spain and France. As we noted earlier, these are some of the nationalities most often to be found in Portuguese football. The 44 players from Brazil were all Brazilians, and the 6 players from Argentina were Argentinians. However, of the 12 players from Spain, 5 were Portuguese; of the 7 players from France, 2 were Portuguese; of 4 players from Greece, 2 were Portuguese and neither of the other two was Greek.

At the end of 2010/11 season, 146 players left the country: 108 foreigners and 38 Portuguese. Thirtyfour players went to Brazil, all of them were Brazilians returning to their country. It should be noted that of the 146 players who left Portuguese football, $30.8 \%$ were players who returned to their countries of origin. Spain was the country that received most players from Portugal: 11 were Portuguese; 6 of other nationalities; and there was one Spaniard returning to his country. Migration to Romania was essentially by foreign players, 7 out of 10 being foreign. The same situation happened with migration to Cyprus, involving 7 players: 5 foreign and 2 Portuguese. Five players each went to England and China. Of the 5 players who left Portugal for China, two were Portuguese, 2 Senegalese and 1 Brazilian.

Rather like a revolving door, the Portuguese clubs' strategy is to buy foreign players 'cheap' and sell them 'expensive'. This strategy is reflected in the value of transfers made by Portuguese clubs in the $2010 / 11$ season. EUR $85,000,000$ were spent on purchasing players earning $176,000,000$ euros in sales, with a profit of EUR $91,000,000 .{ }^{99}$ Soriano, ${ }^{60}$ former Vice President of FC Barcelona, referring to Portuguese football, dubbed this process 'an extraordinary business', consisting of the purchase of relatively unknown players who gain in value for subsequent sale in the major European leagues. Although on different scales, all clubs have been developing the same strategy. This process is repeated to exhaustion, and hence the need to acquire cheap players in affordable markets, in order to sell them for a higher price in more lucrative markets. That is why, in recent years, Portuguese football, due to high transfer values, is an important showcase for players who long to play in other leagues.

\section{Conclusion}

The migratory dynamics of Portuguese football are a consequence of its inclusion in the global sports arena. Like other countries, and at the same time as other flows, Portuguese borders, whether political, cultural or sporting, have also been crossed by the football labour force. Almost inevitably, the landscape 
of Portuguese football is made up of a Foreign Legion of players in motion, some entering and others leaving, of very diverse nationalities.

The significant number of Portuguese players abroad, combined with the large number of foreign players in Portugal, causes some bewilderment. If we take into account the technical skills and tactics, as well as the competitive profiles of the most players, whether in outgoing or incoming flows into Portugal, the similarity of performances can be observed. Something similar can be observed in the general migratory flows in Portugal. According to Baganha, ${ }^{61}$ in early 2000 , the best way of characterizing general migratory processes in Portugal was the simultaneous existence of incoming and outgoing flows of migrants with similar profiles and skills. These foreign immigrants were incorporated in Portugal in exactly the same labour segments that Portuguese emigrants were included in the foreign labour markets. From this perspective, in Portugal, also football can be seen as a turntable that delivers workforce, through imports and exports of players, depending on the institutional structure in which it operates. It imports players predominantly from Latin America, in particular from Brazil, exports players mainly to other European leagues. This metaphor of turntable, applied to football, is the image that best explains the dynamics of migration flows of players in and out of Portuguese football.

Portuguese football operates between the centre and the periphery, among the powerful European leagues and the South American and African championships, reinforcing its semi-peripheral existence. This is a consequence of the way it is positioned as a central country in relation to the peripheral countries, and how it plays its peripheral circumstance to the central countries. Between players coming in and players leaving, whether Portuguese or foreign, the Portuguese football labour market is located in an intermediate position.

The strategy of promoting the incoming migration of young, unknown, accessible players with training potential in order later to encourage outgoing flows of these players, as well as of Portuguese players, and trade them at inflated value in various leagues, reveals how Portuguese football has specialized as part of a broader process in which countries take comparative advantage of a global market. Because the migration of footballers, like migration in general, is not only determined by economic factors, but also by historical and cultural factors, Portuguese clubs seek, in their historical/cultural links with Brazil, to enhance an advantage that other countries do not have.

\section{Notes}

1. UEFA website.

http://pt.uefa.com/uefaeuropaleague/season=2011/matches/round=2000133/match=2006268/ index.html [accessed December 2010].

2. The Primeira Liga is the top professional association football division of the Portuguese football league system.

3. Besson, Poli and Ravenel, Global Player Migration.

4. SJPF, Utilização de jogadores portugueses, 4.

5. Nolasco, "Fintar Fronteiras," 267.

6. Bale and Maguire, The Global Sports Arena.

7. Stead and Maguire, Rite de Passage, 36.

8. Maguire and Pearton, "Global Sport," 175.

9. In 1994, the first major work on sports labour migration (Bale and Maguire, The global sports arena), in addition to football, also made reviews to other sports such as rugby, cricket, ice hockey, basketball or athletics, affected by this migratory phenomenon.

10. Poli, Ravenel, and Besson, "Exporting Countries in world Football."

11. Castles and Miller, The Age of Migration.

12. Bale and Maguire, The Global Sports Arena.

13. The example that best illustrates the sporting miscegenation is the France team that won the World Cup in 1998. This team, which became known as Black, Blanc et Beur is a reflection of the migratory tendencies in French society; Carrard, "L’Equipe de France."

14. In contemporary football the circumstances of Athlétic Bilbao are unique because the team is restricted to athletes who are Basque by birth or descent.

15. In this regard, see the number of foreign-born players in the 2014 football world cup in Brazil. https:// qz.com/219247/which-world-cup-teams-will-field-the-most-foreign-born-players/ [accessed April 2017].

16. Elliott and Maguire, "Thinking Outside," 482.

17. Horne, Sport in Consumer Culture. 
19. Bale and Maguire, The Global Sports Arena.

20. Maguire and Pearton, "Global Sport," 175.

21. Ben-Porat, "The Political Economy of Soccer," 54.

22. Magee and Sugden, "The World at their Feet."

23. Darby, "Africa's place in FIFA."

24. Taylor, "Global Players."

25. Poli, "Production de footballeurs"; Poli, "Understanding Globalization."

26. Takahashi and Horne, "Japanese Football Players."

27. Maguire, "Real Politics."

28. Dimeo and Ribeiro, "I am not a Foreigner Anymore."

29. Carter, In Foreign Fields.

30. Darby, "Moving Players."

31. Maguire and Pearton, "Global Sport," 175.

32. Ruggi, Sonhos em Campo, 44.

33. Poli and Besson, "From the South to Europe," 20.

34. Coelho and Pinheiro, A Paixão do Povo, 219.

35. Simões, "Do Futebolista da...."

36. Domingos, "Urban Football Narratives and the Colonial."

37. Lanfranchi and Taylor, Moving with the Ball; Darby, "African Football Labour," 498.

38. SL Benfica won the European Cup in 1960 and 1961, Sporting CP the Cup Winners Cup in 1964, and in the final stages of the 1966 World Cup Portugal came in third place.

39. Cleveland, "Following the Ball."

40. $\quad$ Coelho and Pinheiro, A Paixão do Povo, 534.

41. Poli, Ravenel, and Besson, "Foreign Players," 2.

42. Nolasco, "Fintar Fronteiras," 267.

43. Poli Ravenel, and Besson, Annual Review, 36,.

44. Poli, Ravenel, and Besson, "Foreign Players," 6.

45. Entity responsible for the organization of professional football in Portugal.

46. http://www.zerozero.pt/.

47. The number of registered clubs per season in the premier league was 16. In the five seasons in question, there were 16 clubs that always remained in the premier league, and seven others who were only there a few times due to relegation.

48. http://esportes.terra.com.br/futebol/noticias/0,,OI5057192-EI1832,00.html [accessed June 2016].

49. According to the Brazilian football Confederation, at the end of the first decade of the twenty-first century, the number of players going abroad per year was greater than 1,000 [www.cbf.com. accessed 2 August 2010].

50. The Treaty of Friendship, Cooperation and Consultation, grants to Brazilians in Portugal a wide range of rights, that in the context of football is reflected in the fact that players from this country do not have foreign status. 51. According to CIES Professional Football Players Observatory, in 2015 Brazil was the country that had most players abroad (1784), followed by Argentina with 929 and France with 758 (Poli, Ravenel, and Besson, "Foreign players," 2).

52. As a result of methodological issues already identified, it is not possible to identify the number of players who are in this situation, which would certainly raise the profile of these players in Portuguese football.

53. Portes, Migrações internacionais.

54. Maguire, "Blade Runners."

55. Magee and Sugden, "The World at their Feet."

56. The football players accounted in the sub-categories 'permanence in the country' are those who, having come to Portugal, remain in the country until our registration of players has finished. This residence includes various situations that may range from five years to last half season.

57. Maguire, "Blade Runners."

58. Magee and Sugden, "The World at their Feet."

59. http://www.futebolfinance.com/as-20-ligas-que-mais-dinheiro-movimentaram-em-transferencias-201011

[accessed December 2011].

60. Soriano, $A$ bola não entra, 52.

61. Baganha, "A Cada Sul o Seu Norte," 142.

\section{Disclosure statement}

No potential conflict of interest was reported by the author. 


\section{Funding}

This work was supported by the Fundação para a Ciência e a Tecnologia [grant number SFRH/BPD/95320/2013]; Strategic Project [grant number UID/SOC/50012/2013].

\section{ORCID}

Carlos Nolasco (http://orcid.org/0000-0002-9932-9222)

\section{References}

Baganha, Maria loannis. "A cada Sul o seu Norte: Dinâmicas migratórias em Portugal." [To Each South its North: Migratory Dynamics in Portugal.] In Globalização, fatalidade ou utopia? [Globalization, Fatality or Utopia?], edited by Boaventura de Sousa Santos, 135-159. Porto: Edições Afrontamento, 2001.

Bale, John The Brawn Drain: Foreign Student-Athletes in American Universities, Chicago, IL: University of Illinois Press, 1991.

Bale, John, and Joseph Maguire The Global Sports Arena: Athletic Talent Migration in an Interdependent World, London: Frank Cass, 1994.

Ben-Porat, Amir. "The Political Economy of Soccer: The Importation of Foreign Soccer Players to the Israeli League." Soccer \& Society 3, no. 1 (2002): 54-68. doi:10.1080/714004872.

Besson, Roger, Raffaele Poli, and Loïc Ravenel Global Player Migration Report 2011, Neuchâtel: PFPO/CIES, 2011.

Carrard, Philippe. "L'Equipe de France du monde': sport and national identity." ['The Team of France of the World': Sport and National Identity.] French Cultural Studies 13, no. 37 (2002): 65-82.

Carter, Thomas. In Foreign Fields. The Politics and Experiences of Transnational Sport Migration, London: Pluto Press, 2011.

Castles, Stephen, and Miller Mark The Age of Migration. International Population Movements in the Modern World, New York: Palgrave Macmillan, 2003.

Cleveland, Todd. "Following the Ball: African Soccer Players, Labor Strategies and Emigration Across the Portuguese Colonial Empire, 1949-1975." Cadernos de Estudos Africanos 26, no. 2013). http://cea.revues.org/1109. doi : $10.4000 /$ cea.1109.

Coelho, João Nuno, and Francisco Pinheiro. A Paixão do Povo: História do Futebol em Portugal [The Passion of the People: History of Football in Portugal]. Porto: Edições Afrontamento, 2002.

Darby, Paul. "Africa's Place in FIFA's Global Order: A Theoretical Frame." Soccer \& Society 1, no. 2 (2000): 36-61. doi:10.1080/14660970008721264.

Darby, Paul. "African Football Labour Migration to Portugal: Colonial and Neo-Colonial Resource." Soccer \& Society 8, no. 4 (2007): 495-509. doi:10.1080/14660970701440774.

Darby, Paul. "Moving Players, Traversing Perspectives: Global Value Chains, Production Networks and Ghanaian Football Labour Migration." Geoforum, no. 50 (2013): 43-53. doi:10.1016/j.geoforum.2013.06.009.

Dimeo, Paul, and Carlos Henrique Ribeiro “I am Not a Foreigner Anymore': A Micro-Sociological Study of the Experiences of Brazilian Futsal Players in European Leagues." Movimento 15, no. 2 (2009): 33-44.

Domingos, Nuno. "Urban Football Narratives and the Colonial Process in Lourenço Marques." The International Journal of the History of Sport 28, no. 15 (2011): 2159-2175. doi:10.1080/09523367.2011.622114.

Elliott, Richard, and Joseph Maguire. "Thinking Outside of the Box: Exploring a Conceptual Synthesis for Research in the Area of Athletic Labor Migration." Sociology of Sport Journal 25, no. 4 (2008): 482-497.

Horne, John. Sport in Consumer Culture, New York: Palgrave, 2006.

Lanfranchi, Pierre, and Matthew Taylor. Moving with the Ball. The Migrations of Professional Footballers. Oxford: Berg, 2001.

Magee, Jonathan, and John Sugden. "The World at their Feet. Professional Football and International Labor Migration." Journal of Sport \& Social Issues 26, no. 4 (2002): 421-437. doi:10.1177/0193732502238257.

Maguire, Joseph. "Blade Runners: Canadian Migrants, Ice Hockey, and the Global Sports Process." Journal of Sport and Social Issues 20, no. 3 (1996): 335-360doi:10.1177/019372396020003007.

Maguire, Joseph. "'Real Politic' or 'Ethically Based': Sport, Globalization, Migration and Nation-state Policies." Sport in Society 11, no. 4 (2008): 443-458. doi:10.1080/17430437.2011.603557.

Maguire, Joseph, and Robert Pearton. "Global Sport and the Migration Patterns of France '98 World Cup Finals Players: Some Preliminary Observations." Soccer \& Society 1, no. 1 (2000): 175-189. doi:10.1080/14660970008721257.

Nolasco, Carlos. "Fintar Fronteiras. Migrações Internacionais no Futebol Português." [Dribbling Borders. International Migration in the Portuguese Football]. PhD diss., University of Coimbra, Portugal, 2013. 
Poli, Raffaele. "Production de footballeurs, reseaux marchands et mobilites professionnelles dans léconomie globale. Le cas de joueurs africains en Europe." [Production of Footballers, Market Networks and Professional Mobility in the Global Economy. The Case of African Players in Europe.] PhD diss., Université de Neuchâtel, 2008.

Poli, Raffaele. "Understanding Globalization through Football. The New International Division of Labour, Migratory Channels and Transnational Trade Circuits." International Review for the Sociology of Sport 45, no. 4 (2010): 491-506. doi:10.1177/1012690210370640.

Poli, Raffaele, and Roger Beson. "From the South to Europe. A Comparative Analysis of African and Latin American Football Migration." In Sport and Migration: Borders, Boundaries and Crossings, edited by Joseph Maguire, and Mark Falcous, 15-30., London: Routledge, 2011.

Poli, Raffaele, Loïc Ravenel, and Roger Besson. Annual Review of the European Football Players' Labour Market. Neuchâtel: CIES, 2009.

Poli, Raffaele, Loïc Ravenel, and Roger Besson. "Exporting Countries in World Football." CIES Football Observatory Monthly Report,, no. 8 (2015). Accessed June 2016. http://www.footballobservatory.com/IMG/pdf/mr08_eng.pdf

Poli, Raffaele, Loïc Ravenel, and Roger Besson. "Foreign Players in Football Teams." CIES Football Observatory Monthly Report, no. 12 (2016) (2016). Accessed June 2016. http://www.footballobservatory.com/IMG/sites/mr/mr12/en/

Portes, Alejandro. Migrações internacionais. Origem, tipos e modos de incorporação [International Migrations. Origin, Types and Modes of Incorporation]. Oeiras: Celta, 1999.

Ruggi, Lennita. Sonhos em Campo. Transferências Internacionais de futebolistas brasileiros [Dreams in the Field. International Transfers of Brazilian Footballers]. São Paulo: Editora Blücher, 2009.

Santos, Ana. "Eusébio, o processo de construção de um ícone da nação." [Eusébio, the Process of Building a Nation's Icon.] Manifesto, no. 6 (2004): 80-91.

Simões, António. "Do futebolista da... Lazio, o busto da República e a estátua do Marquês." [From the Footballer of ... Lazio, the Bust of the Republic and the Statue of the Marquês.] A Bola, no. 23 (2010).

SJPF. Época 2010/2011. Utilização de Jogadores Portugueses e Estrangeiros [Use of Portuguese and Foreign Players]. Lisboa: Sindicato dos Jogadores Profissionais de Futebol, 2011.

Soriano, Ferran. A bola não entra por acaso. O que o futebol tem a ensinar à gestão [The Ball Does not Come by Chance. What Football has to Teach Management], Lisboa: Gestão Plus, 2010.

Stead, David, and Joseph Maguire. "Rite De Passage" or Passage to Riches? The Motivation and Objectives of Nordic/ Scandinavian Players in English League Soccer." Journal of Sport and Social Issues 24, no. 1 (2000): 36-60.

Takahashi, Yoshio, and John Horne. "Japanese Football Players and the Sport Talent Migration Business." In Football goes East: The Business and Culture of the People's Game in East Asia, edited by Wolfram Manzenreiter, and John Horne, 69-86. Londres: Routledge, 2004.

Taylor, Matthew. "Global Players? Football, Migration and Globalization, c. 1930-2000." Historical Social Research 31, no. 1 (2006): 7-30. 